\title{
Machine Learning to Improve Prognosis Prediction of Early Hepatocellular Carcinoma After Surgical Resection [Corrigendum]
}

Ji GW, Fan Y, Sun DW, et al. J Hepatocell Carcinoma. 2021;8:913-923.

The authors have advised that the data reported in the study was obtained from SEER Research Data and not from the SEER-Medicare database as indicated in the published paper.

The authors apologise for this error.

\section{Publish your work in this journal}

The Journal of Hepatocellular Carcinoma is an international, peerreviewed, open access journal that offers a platform for the dissemination and study of clinical, translational and basic research findings in this rapidly developing field. Development in areas including, but not limited to, epidemiology, vaccination, hepatitis therapy, pathology and molecular tumor classification and prognostication are all considered for publication. The manuscript management system is completely online and includes a very quick and fair peer-review system, which is all easy to use. Visit http://www.dovepress.com/ testimonials.php to read real quotes from published authors. 